九病虫研会報 $63: 71-78(2017)$

Kyushu Pl. Prot. Res. 63 : 71-78（2017）

\title{
マンゴー加温栽培におけるチャノキイロアザミウマの 秋冬季の発生推移と越冬場所
}

\author{
西 菜穂子 ${ }^{\dagger *} \cdot$ 宮路 克彦* \\ （鹿児島県農業開発総合センター果樹部）
}

\begin{abstract}
Overwintering sites and autumn-winter prevalence of yellow tea thrips (Scirtothrips dorsalis Hood) in mango under plastic house conditions. Nahoko Nishi ${ }^{\dagger *}$ and Katsuhiko Miyaji* (Fruit Tree Division, Kagoshima Prefectural Institute for Agricultural Development, Tarumizu, Kagoshima 891-2112, Japan)
\end{abstract}

Scirtothrips dorsalis is known as a pest in mango. Strain C and YT of $S$. dorsalis coexisted on mango in Kagoshima Prefecture. We investigated the overwintering sites of $S$. dorsalis in mango under plastic house conditions. Strain YT caught by yellow sticky traps and ground traps were observed at a minimum level of activity for four months from November to late February, so they seemed to overwinter in mango. On the other hand, strain C was observed from a number of adults caught by the traps from October to November, after that they increased until spring. This result establishes strain $\mathrm{C}$ seemed to active in mango throughout autumn-winter. Strain C was also observed in flower buds of mango that were not caught by the yellow sticky traps. This result suggests that strain $C$ propagated and emerged from buds throughout the autumn-winter.

Keywords : mango, yellow tea thrips, strain C, strain YT

\section{緒言}

鹿児島県におけるマンゴーMangifera indica L.の 栽培は，主にビニルハウスや硬質プラスチックハウス 等を用いた施設で行われており，県本土および熊毛地 域では加温栽培, 奄美群島では無加温栽培されている。 本県のマンゴーは2014年に栽培面積, 生産量とも沖縄 県, 宮崎県に次いで全国第 3 位となっている（農林水 産省, 2014)。

マンゴーでは様々な害虫の寄生，加害が報告されて いるが（仲宗根ら，1996；山口ら，2006），その中で もチャノキイロアザミウマは新梢，新葉および幼果等 の柔らかい組織を加害し, 果実の商品価值を低下させ

nishi-nahoko@pref.kagoshima.lg.jp

* 現在 鹿児島県農業開発総合センター

* Present address: Kagoshima Prefectural Institute for Agricultural Development, Minamisatsuma, Kagoshima 894-3401, Japan
るため（大林，2003；山口，2007）, 本県マンゴー栽 培においても重要害虫として位置づけられている。ま た，日本に以前から分布していたと考えられる在来系 統 (YT 系統) とは遺伝的に異なりピーマンおよびシ シトウに強い寄生性を示す海外由来の C 系統（Toda et al., 2014）が，本県マンゴー栽培でも2009年に確 認された（鹿児島県病害虫防除所，2010）。その後の 詳細な調查において鹿児島県内19市町村で広域に発生 していることが明らかとなった（吉松ら，2014）。

近年，本県マンゴー栽培では，スワルスキーカブリ ダニAmblyseius swirskii Athias-Henriotを利用した IPM 体系が普及してきている。天敵放飼は常に発生 前から発生初期に行うこととされており（山中, 2009），モニタリング用としての黄色粘着トラップの 利用が重要視されてきたが, 秋冬季には黄色粘着卜 ラップにほとんど誘殺されないことから，チャノキイ ロアザミウマの発生に気づかず放飼して，その効果が 不安定な事例がみられた。実際にマンゴーにおける チャノキイロアザミウマの秋冬季の発生生態はほとん 
ど明らかにされておらず，この時期の発生生態を解明 した上で IPM 体系を確立することが重要と考えられ た。

そこで, チャノキイロアザミウマ 2 系統のマンゴー 加温栽培における秋冬季の系統の発生消長および生息 場所について調査したので報告する。

\section{材料と方法}

\section{1. 試験場所および供試作物}

鹿児島県垂水市本城の鹿児島県農業開発総合セン ター果樹部内のビニルハウス $(2.4 \mathrm{a})$ で16号鉢植えの マンゴー品種「アーウィン (Irwin)」(2012年 7 月 3 年生苗植栽）15本を用いて2014～2015年，2015～2016 年の秋冬季に調査した。栽培体系は $7 \sim 8$ 月に収穫出 荷する作型で，秋冬季のハウス内の温度管理は2014年 10月31日に，2015年は11月26日にビニル密閉後，最低 温度を $10^{\circ} \mathrm{C}$ になるよう設定し, 加温した。頂芽の 8 割 で花芽を確認した後，2014年12月19日，2016年 1 月 4 日から 1 日あたり $0.5^{\circ} \mathrm{C}$ 昇温を開始し, 最低温度を $15^{\circ} \mathrm{C}$ とした。供試樹には, 試験期間中に農薬を使用せ ず，肥培管理などは本県の栽培基準に従った。

\section{2. 黄色粘着トラップによる系統別のチャノキイロ} アザミウマ成虫誘殺状況

トラップによる成虫の秋冬季の誘殺消長調査は, 2014年11月 4 日から 2015年 3 月 26 日，2015年には成虫 両 2 系統の誘殺虫数量を観察するため, 9月14日から 2016年 3 月29日まで，ほぼ10日間隔で行った。トラッ プには黄色粘着板（アリスタライフサイエンス株式会 社製・ホリバーイエロー®）を用い，ハウス内にマン ゴー樹と近接するよう地上約 $1.5 \mathrm{~m}$ の高さに 2 基設置 した。誘殺された成虫は実体顕微鏡下で計数後, $0.5 \mathrm{ml}$ マイクロチューブに 1 頭ずつ採集し, 種を同定する遺 伝子診断の試料とした。ただし，2015年 9 月24日には 600 頭および10月 5 日には285頭と誘殺虫数が多かった ため，それぞれ106頭，84頭を無作為に採集して遺伝 子診断に供し，それぞれの期間の総誘殺虫数に各系統 の割合を乗じて系統別の誘殺虫数を推定した。

\section{3. 素焼き鉢を使用した出現トラップによるチャノ} キイロアザミウマ誘殺状況

調査は地表から羽化する成虫数を調査するために, 2014年12月15日～2015年 4 月 6 日，2015年 9 月14日〜 2016年 4 月 8 日までほぼ10日間隔で行った。出現卜 ラップは Masui（2007）の方法を参考に, マンゴーを 植えた 16 号鉢の地表に 5 号素焼き製植木鉢を底面が上 になるように置き，水抜き穴に金竜スプレー（丸善薬
品産業株式会社）を吹き付けたプラスチックシャーレ （直径 $5 \mathrm{~cm}$ ）をかぶせ，使用した。これを 1 錬当たり 4 基設置し，10鉢で調査した。誘殺された成虫は実体 顕微鏡下で計数し, 種を同定する遺伝子診断の試料と した。ただし，2015年 9 月24日は2,458頭，10月 5 日 は1,426頭と誘殺虫数が多かったため, それぞれ200頭, 140頭を無作為に採集して遺伝子診断に供し，それぞ れの期間の総誘殺虫数に各系統の割合を乗じて系統別 の誘殺虫数を推定した。

\section{4. マンゴーでの越冬状況調査}

(1) 芽, 花穂の浸漬調査

調査は2014年12月26日～2015年 2 月 6 日，2015年〜 2016年には暖冬の影響で花芽形成が遅れたため, 2016 年 1 月29日〜 3 月29日までほぼ10日間隔で行った。浸 漬は施設内のマンゴー15樹全体から $7 \sim 8$ 個の芽, 花 穂を任意に抽出し，1芽ずつ中性洗片（ママレモン， ライオン株式会社） 5,000 倍希釈溶液 $400 \mathrm{ml}$ を入れた ビーカーに浸漬し，10回程度枝を振り，寄生している 虫を洗い落とした。浸漬の際に芽の下の旧葉は切り 取った。 5 分程度静置した後, 上澄み液を捨て残液を $250 \mathrm{ml}$ 広口瓶（アイボーイ, アズワン株式会社）に入 れた。これをろ紙（定性ろ紙No. 2, ADVANTEC） でろ過し, 実体顕微鏡下で生育ステージ別に虫数を計 数した。採集した本虫はマイクロチューブに1頭ずつ 採集し, 種を同定する遺伝子診断の試料とした。なお， 浸漬した芽は次回の調查では調查対象から除いた。

(2) 芽の分解調查

浸漬調查で展開していない芽（以下「閉じている 芽」とする, Fig. 1A）, 芽先が開いただけの芽（以下, 「開き始めた芽」とする, Fig. 1B）ではチャノキイロ アザミウマの寄生が確認できなかった。そのため, 2015 年 1 月 16 日， 2 月 6 日，2015年10月 28 日， 11 月 17 日に 1 15芽を採集して, 実体顕微鏡下でピンセット を使用して芽を分解しながら寄生状況を生育ステージ 別に調查した。採集した本虫はマイクロチューブに 1 頭ずつ採集し，種を同定する遺伝子診断の試料とした。

\section{5. 樹上での越冬状況調査}

樹上での本種の越冬場所を探索するためにファイト トラップ（小池ら，2000）を2014年11月17日に設置し た。トラップは, マジックテープ両面タイプ (エス エス産業株式会社, 幅 $2 \mathrm{~cm}$, 長さ $8 \sim 30 \mathrm{~cm}$ ) に黒色 毛系（毛70\%，アクリル30\%, 並太）を5往復で㙋り 付け, マンゴー先端の緑枝部位に任意に 10 15個 / 樹, 地際に接した主幹部, 主幹の分岐部の上の木質化した 2 枝にそれぞれ 5 個/樹ずつ巻き付けた。これを 5 樹 


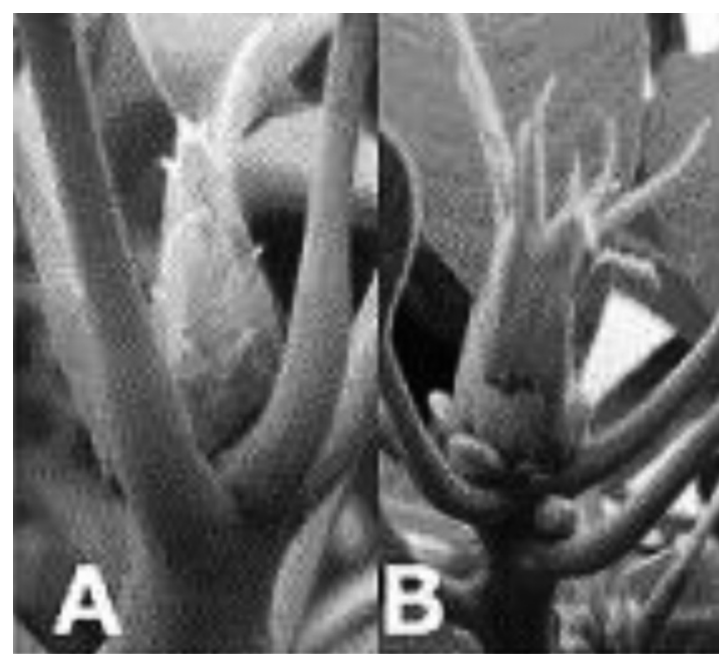

Fig. 1. The stage of bud breaks in mango. A Before breaking. B After breaking, whose bract are opening.

に対して行った。トラップは2015年 1 月 9 日に取り外 し，その中に蝟集したチャノキイロアザミウマを実体 顕微鏡下で生育ステージ別に計数した。

6. チャノキイロアザミウマの遺伝子診断法による 系統調查

チャノキイロアザミウマの全核酸を PrepMan ${ }^{\mathrm{TM}}$ Ultra Sample Preparation Reagent (Applied Biosystems, Foster City, CA）で, プロトコールに従 い，抽出した。PCR 法は Toda et al.（2014）の方法 に準じ，標的領域は rDNA-ITS2領域，プライマーに は ThripsITSF, Thrips ITSR, SdITSMarkerF3およ び SdITSMarkerF7の 4 種を使用した。反応液の組成 は, 鋳 型 DNA0.5 $\mu \mathrm{l}, 2.5 \mathrm{mMdNTP} 1 \mu \mathrm{l}, 10 \times \mathrm{ExTaq}$

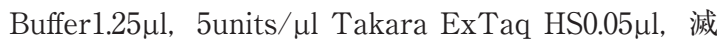
菌水 $9.2 \mu \mathrm{l}$ と各 $20 \mu \mathrm{M}$ プライマー $0.125 \mu \mathrm{l}$ の合計 $10 \mu \mathrm{l}$ と し, 合成反応はサーマルサイクラーTaKaRa PCR Thermal cycler Dice ${ }_{\circledast}$ (タカラバイオ株式会社）に より反応させた。反応条件は $94^{\circ} \mathrm{C} 9$ 分間を 1 サイクル, 続いて $94^{\circ} \mathrm{C} 15$ 秒, $56^{\circ} \mathrm{C} 15$ 秒, $72^{\circ} \mathrm{C} 30$ 秒を 35 サイクル, さらに $72^{\circ} \mathrm{C}$ で7分間を 1 サイクルとした。得られた PCR 増幅産物は $2.5 \%$ アガロースゲルおよび泳動用に TAE 緩衝液を使用し, 40分間電気泳動した後, ゲル を GelRed Nucleic Acid Strain (BIOTIUM) (×10,000, TAE）で染色し，UV 照射下で確認した。
結

果

1. 黄色粘着トラップによる系統別のチャノキイロ アザミウマ成虫誘殺状況

黄色粘着トラップによる本種成虫 2 系統の誘殺消長 を Fig. 2に示した。供試したビニルハウスには 2 系統 が混発して抢り，2014年～2015年，2015年～2016年の 発生の主体は C 系統であった（Fig. 3）。2014年11月 ～2015年 3 月には YT 系統は2014年12月25日に初めて 0.1 頭/日/トラップ誘殺され, それ以降の誘殺数は $0 \sim 0.2$ 頭 / 日 / トラップの範囲で推移した。一方，C 系統は 12 月 25 日に初めて 0.05 頭 / 日 / トラップ誘殺さ れ，1月 5 日から増加し始め, 3月26日に5.4頭/日／ トラップまで急増した。2015年 9 月〜2016年 3 月には YT 系統は 9 月 24 日に2.1頭 / 日 / トラップ誘殺された が, その後の誘殺数は $0 \sim 0.8$ 頭/日/トラップの範 囲であった。それに対して C 系統は 9 月中旬に 28.2 頭 /日/トラップ誘殺された後, 誘殺数は 10 月下旬には 0.2 頭/日/トラップにまで減少した。その後, C 系 統は 12 月以降に誘殺数が増加し 3 月中旬にかけて 11.3 頭 / 日 / トラップまで増加した。

\section{2. 素焼き鉢を使用した出現トラップによるチャノ} キイロアザミウマ誘殺状況

マンゴー錸内に設置した出現トラップに誘殺された 成虫の誘殺消長を Table 1に示した。2014年12月〜 2015年 4 月には, YT 系統は2015年 3 月26日まで誘殺 されず，4月 6 日に0.01頭／日／トラップ誘殺された。 一方, C 系統は 2 月 6 日を除く全ての調査期間で誘殺 された。2015年 9 月〜2016年 4 月には, YT 系統は 9 〜10月にかけ誘殺虫数は減少し, 10月14日に0.05頭／ 日/トラップ誘殺された後は，3月29日に0.01頭／日 / トラップ誘殺されたのみであった。それに対して C 系統は 9 月24日に23.8頭 / 日/トラップ誘殺された後 誘殺数は11月16日に 0 頭 / 日 / トラップ減少した。そ の後 C 系統は $0 \sim 0.02$ 頭 / 日 / トラップの範囲で誘殺 され，2月 8 日以降に誘殺数が増加し，3月29日には 1.27 頭 /日/トラップまで増加した。

\section{3. マンゴー芽での越冬状況調査}

(1) 芽の浸漬調査

マンゴー芽の浸漬により採集された寄生虫数を Table 2 に示した。2014年〜2015年には, 調查を開始 した2014年12月26日から全ての調査で $\mathrm{C}$ 系統成虫の 寄生が認められた。C 系統の蛹および幼虫は2015年 1 月 5 日以降に寄生が認められた。YT系統は 2015 年 1 月16日に成虫の寄生，2月 6 日に幼虫の寄生が認めら 


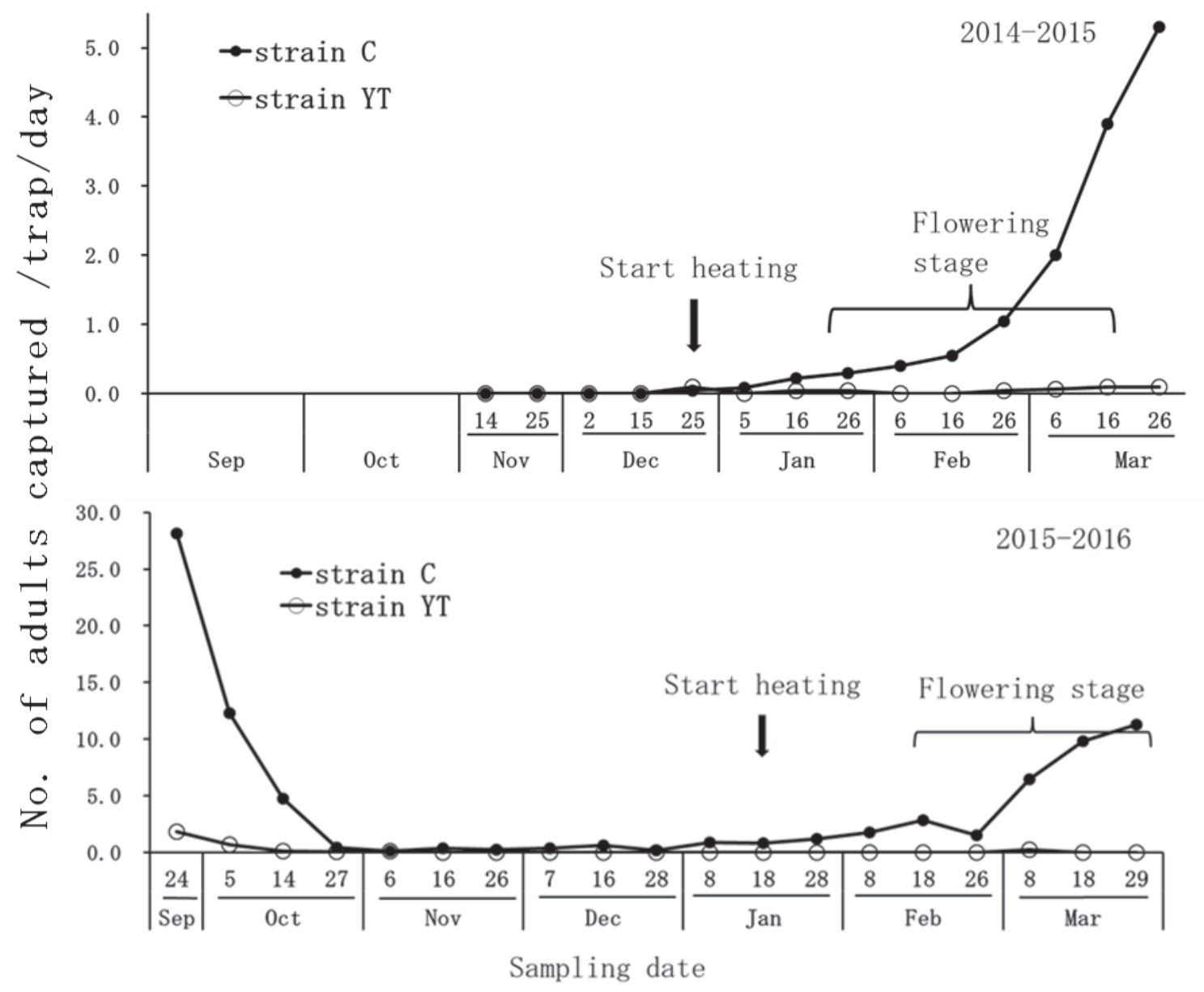

Fig. 2. Prevalence in the number of $S$. dorsalis adults captured by yellow sticky traps in mango under plastic house during autumn-winter season. Differentiation of the two strains was analyzed multiplex-PCR method.

れた。2016年には調査を開始した 1 月29日から全ての 調查で C 系統の成虫, 蛹抢よび幼虫の寄生が認めら れた。一方, YT 系統は2016年 3 月10日のみ成虫, 幼 虫の寄生が認められた。

(2) 芽の分解調查

Fig. 1に示した生育ステージ別の芽中のチャノキイ ロアザミウマ寄生虫数を Table 3に示した。チャノキ イロアザミウマは2015年 2 月 6 日に開き始めた芽の中 にC系統の成虫の寄生が認められた。2015年は黄色 粘着トラップの誘殺虫数が極少ない時期に芽を採集し, 分解した結果，10月28日にC 系統の成幼虫，11月17 日にC 系統の成虫の寄生を開き始めた芽でのみ確認 した。YT系統は2015年冬季と秋季の各 2 回ずつの調 査では寄生は確認できなかった。

\section{4. 樹上での越冬状況調査}

2014年11月17日にマンゴーの枝，幹にファイトト ラップを設置し，53日後（2015年 1 月 9 日）に蝟集状 況を調查した結果，設置した 5 樹のうち 2 樹の地際に 接した主幹部に巻き付けたトラップからのみ, 成虫が 1 頭ずつ確認された（Table 4)。この 2 頭については 遺伝子診断を行わなかった。

\section{考察}

一般にチャノキイロアザミウマは硬化した葉，枝扔 よび成熟した果実には生息しないとされており（西野 ら，1988)，マンゴーにおいても同様な結果が示され ている（山口，2007）。鹿児島県のマンゴー施設栽培 では収穫後の $8 \sim 9$ 月上旬に剪定を行い，10月まで新 


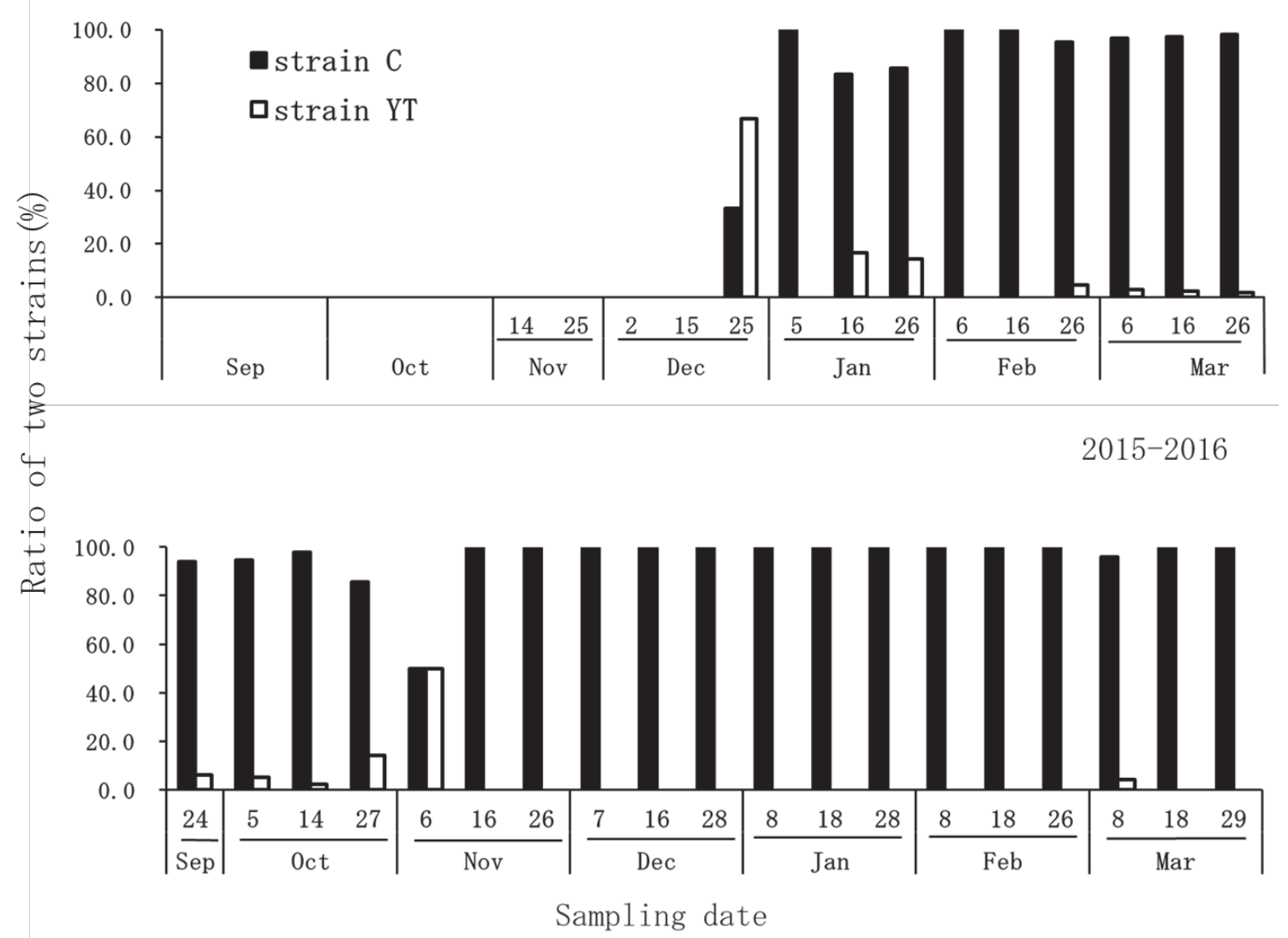

Fig. 3. Ratio of two strains of $S$. dorsalis adults captured by yellow sticky traps in mango under plastic house during autumn-winter. Differentiation of the two strains was analyzed multiplex-PCR method.

梢を発生，硬化させて次作の花芽形成を促す。その後 11月から花芽が出蕾する12〜 1 月までの約 2 ～ 3 か月 間は本種が寄生できる部位は少ない。

黄色粘着トラップおよび出現トラップによるチャノ キイロアザミウマ 2 系統の秋冬季の誘殺消長を調査し た結果, 本試験に供した八ウスでは C 系統の比率が 高かった。しかし，YT 系統は10月以降 3 月中旬まで ほとんど誘殺されないのに対し，C系統は少ないなが らも誘殺され，2系統の発生は異なることが示唆され た。チャでは本種成虫は平均気温が $10^{\circ} \mathrm{C}$ 以下となる 12 月中旬から 3 月中旬までの約 3 か月間には活動は非常 に低下し，主として枝幹部で，一部は葉層部で越冬す るとされている（岡田・工藤，1982）。C 系統は黄色 粘着トラップの調查では誘殺数は減少するものの10〜
11月でも誘殺され，出現トラップでも10月以降少ない ながらも誘殺された。黄色粘着トラップなどで誘殺が 減少する秋冬季の生息状況について調查した結果, 芽 の浸漬調査では，C系統は秋冬季でも芽で増殖してい ることが示された。日本に侵入したC 系統は, インド, タイおよび台湾由来の個体群とされていることから (土田, 2015), 芽に寄生・増殖していても秋冬季の黄 色粘着トラップに誘殺される C 系統成虫数が少ない のは気温の低い影響で飛翔しにくいのではないかと推 察される。柴尾・田中（2003）はブドウでは短日条件 によって雌成虫の生存期間が長くなり, 生殖休眠する ことを示唆しているが, 今回の調査では C 系統は短 日条件下, 好適増殖源がないときでも芽で生息, 増殖 しており，生殖休眠しないことが示唆された。ブドウ 
Table 1. Prevalence in the number of adult emergence of $S$. dorsalis on the ground in mango under plastic house during autumn-winter

\begin{tabular}{|c|c|c|c|c|c|c|c|c|c|c|c|c|}
\hline \multirow[b]{3}{*}{ Strain } & \multirow[b]{3}{*}{ a) } & \multicolumn{11}{|c|}{ Sampling date, 2014-2015 } \\
\hline & & 25 & 5 & 16 & 26 & 6 & 16 & 26 & 6 & 16 & 26 & 6 \\
\hline & & Dec & \multicolumn{3}{|c|}{ Jan } & \multicolumn{3}{|c|}{ Feb } & \multicolumn{3}{|c|}{$\operatorname{Mar}$} & Apr \\
\hline \multicolumn{13}{|l|}{$\mathrm{C}$} \\
\hline \multirow{4}{*}{ YT } & Mean & 0.01 & 0.02 & 0.03 & 0.03 & 0.00 & 0.01 & 0.01 & 0.01 & 0.13 & 0.11 & 0.69 \\
\hline & $\mathrm{SD}$ b) & 0.01 & 0.01 & 0.03 & 0.02 & 0.00 & 0.01 & 0.01 & 0.01 & 0.05 & 0.05 & 0.21 \\
\hline & Mean & 0.00 & 0.00 & 0.00 & 0.00 & 0.00 & 0.00 & 0.00 & 0.00 & 0.00 & 0.00 & 0.01 \\
\hline & $\mathrm{SD}$ & 0.00 & 0.00 & 0.00 & 0.00 & 0.00 & 0.00 & 0.00 & 0.00 & 0.00 & 0.00 & 0.01 \\
\hline
\end{tabular}

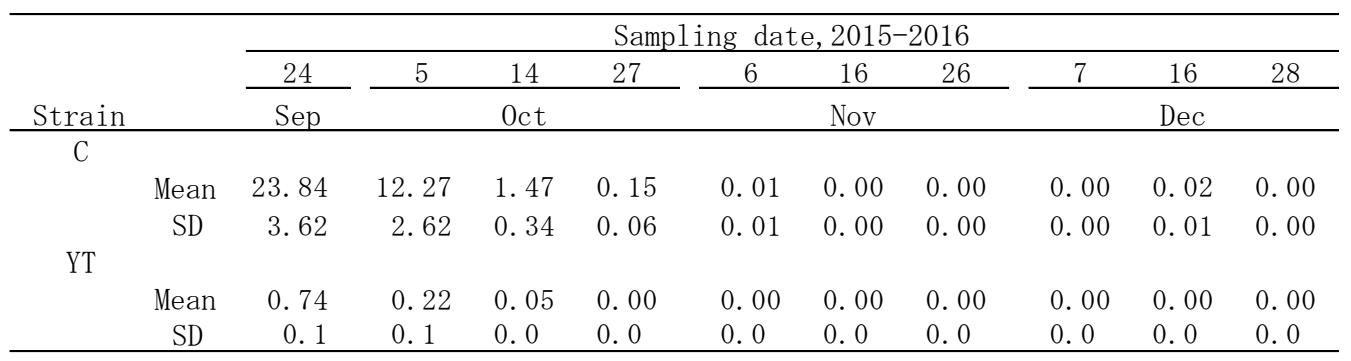

\begin{tabular}{|c|c|c|c|c|c|c|c|c|c|c|c|}
\hline & & \multicolumn{10}{|c|}{ Sampling date, 2015-2016 } \\
\hline & & 8 & 18 & 28 & 8 & 18 & 26 & 8 & 18 & 29 & 8 \\
\hline \multicolumn{2}{|l|}{ Strain } & \multicolumn{3}{|c|}{ Jan } & \multicolumn{3}{|c|}{ Feb } & \multicolumn{3}{|c|}{ Mar } & Apr \\
\hline \multicolumn{12}{|l|}{$\mathrm{C}$} \\
\hline \multirow{4}{*}{ YT } & Mean & 0.01 & 0.02 & 0.02 & 0.07 & 0.09 & 0.10 & 0.29 & 0.73 & 1. 27 & 1.22 \\
\hline & SD & 0.0 & 0.0 & 0.0 & 0.1 & 0.1 & 0.0 & 0.2 & 0.3 & 0.6 & 1.2 \\
\hline & & & & & & & & & & & \\
\hline & $\begin{array}{r}\text { Mean } \\
\text { SD }\end{array}$ & $\begin{array}{l}0.00 \\
0.0\end{array}$ & $\begin{array}{r}0.00 \\
0.0\end{array}$ & $\begin{array}{r}0.00 \\
0.0\end{array}$ & $\begin{array}{r}0.00 \\
0.0\end{array}$ & $\begin{array}{r}0.00 \\
0.0\end{array}$ & $\begin{array}{r}0.00 \\
0.0\end{array}$ & $\begin{array}{r}0.00 \\
0.0\end{array}$ & $\begin{array}{r}0.00 \\
0.0\end{array}$ & $\begin{array}{r}0.01 \\
0.0\end{array}$ & $\begin{array}{r}0.00 \\
0.0\end{array}$ \\
\hline
\end{tabular}

a) Differentiation of the two strains was analyzed multiplex-PCR method. b) Standard deviation $(\mathrm{n}=10)$.

では本種は樹皮部や落葉および土壌中で越冬している ことが報告されており（柴尾ら，1991）, 今回のファ イトトラップによる調査でもマンゴーの地際に接した 主幹部に設置したファイトトラップで本種が捕獲され た。本試験では，マンゴーの開き始めた芽では C 系 統の寄生は確認できたが, 閉じている芽では寄生を確 認することはできなかった。マンゴーが好適増殖源と ならない時期にハウス内のムラサキカタバミに成虫， 幼虫が寄生しているのを観察しており，マンゴー以外 の寄生植物上で生息すると考えられるため, 今後調査 を行いたい。

本研究の結果から C 系統は，生殖休眠せず秋冬季 にも連続的に発生し, 出蕾〜開花期以降にハウス内の
温度の上昇とともに密度が上昇することが示唆された。 スワルスキーカブリダニの放飼時期である花穂伸長期 にチャノキイロアザミウマの密度が高いことがスワル スキーカブリダニによる密度抑制に失敗する要因のひ とつと考えられた。今後は，スワルスキーカブリダニ による密度抑制が安定化できる秋冬季のチャノキイロ アザミウマの防除体系を検討し，他の病害虫に対する 殺虫, 殺菌剂を含めて総合的にマンゴーでの IPM 体 系を実践する必要がある。 
Table 2. Fluctuations in the number of $\boldsymbol{S}$. dorsalis per mango bud collected by the washing method

\begin{tabular}{|c|c|c|c|c|c|c|c|}
\hline \multirow{2}{*}{$\begin{array}{l}\text { Sampling } \\
\text { years }\end{array}$} & \multirow[t]{2}{*}{ Strain $^{\text {a) }}$} & \multirow{2}{*}{$\begin{array}{l}\text { Development } \\
\text { stage }\end{array}$} & \multicolumn{5}{|c|}{ No. of S. dorsalis /bud } \\
\hline & & & 26-Dec & 5-Jan & 16-Jan & 26-Jan & $6-\mathrm{Feb}$ \\
\hline \multirow{4}{*}{$2014-2015$} & $\mathrm{C}$ & Larva and pupa & 0.0 & 2.4 & 1.9 & 0.1 & 1.1 \\
\hline & & Adult & 1.3 & 1.0 & 2.1 & 0.3 & 2.4 \\
\hline & YT & Larva and pupa & 0.0 & 0.0 & 0.0 & 0.0 & 0.6 \\
\hline & & Adult & 0.0 & 0.0 & 0.1 & 0.0 & 0.0 \\
\hline
\end{tabular}

\begin{tabular}{|c|c|c|c|c|c|c|c|c|c|}
\hline \multirow{2}{*}{$\begin{array}{l}\text { Sampling } \\
\text { years }\end{array}$} & \multirow[t]{2}{*}{ Strain $^{\text {a) }}$} & \multirow{2}{*}{$\begin{array}{l}\text { Development } \\
\text { stage }\end{array}$} & \multicolumn{7}{|c|}{ No. of S. dorsalis } \\
\hline & & & 29-Jan & $9-\mathrm{Feb}$ & 19-Feb & 1-Mar & 10-Mar & 18-Mar & 29-Mar \\
\hline \multirow{4}{*}{ 2015-2016 } & $\mathrm{C}$ & Larva and pupa & 6.4 & 3.9 & 3.0 & 3.7 & 7.7 & 4. 7 & 12.9 \\
\hline & & Adult & 6.8 & 35.0 & 5.9 & 7.1 & 5.4 & 17.0 & 9.9 \\
\hline & YT & Larva and pupa & 0.0 & 0.0 & 0.0 & 0.0 & 0.3 & 0.0 & 0.0 \\
\hline & & Adult & 0.0 & 0.0 & 0.0 & 0.0 & 0.1 & 0.0 & 0.0 \\
\hline
\end{tabular}

a) Differentiation of the two strains was analyzed multiplex-PCR method.

Table 3. Number of larva and pupa, adult of Strain C and Strain YT of S. dorsaris in the bud in mango

\begin{tabular}{|c|c|c|c|c|c|c|c|c|c|}
\hline & & \multicolumn{4}{|c|}{ 2014-2015 } & \multicolumn{4}{|c|}{2015} \\
\hline & & \multicolumn{2}{|c|}{ 16-Jan } & \multicolumn{2}{|c|}{$6-\mathrm{Feb}$} & \multicolumn{2}{|c|}{28 -Oct } & \multicolumn{2}{|c|}{ 17-Nov } \\
\hline Strain & $\begin{array}{l}\text { Development } \\
\text { stage }\end{array}$ & $\begin{array}{l}\text { Before } \\
\text { breaking }\end{array}$ & $\begin{array}{l}\text { After }{ }^{\text {a) }} \\
\text { breaking, } \\
\text { whose bract } \\
\text { are opening }\end{array}$ & $\begin{array}{l}\text { Before } \\
\text { breaking }\end{array}$ & $\begin{array}{l}\text { After } \\
\text { breaking, } \\
\text { whose bract } \\
\text { are opening }\end{array}$ & $\begin{array}{l}\text { Before } \\
\text { breaking }\end{array}$ & $\begin{array}{l}\text { After } \\
\text { breaking, } \\
\text { whose bract } \\
\text { are opening }\end{array}$ & $\begin{array}{l}\text { Before } \\
\text { breaking }\end{array}$ & $\begin{array}{l}\text { After } \\
\text { breaking, } \\
\text { whose bract } \\
\text { are opening }\end{array}$ \\
\hline \multicolumn{10}{|l|}{$\mathrm{C}$} \\
\hline & Larva and pupa & 0.0 & 0.0 & 0.0 & 0.0 & 0.0 & 0.3 & 0.0 & 0.0 \\
\hline & Adult & 0.0 & 0.0 & 0.0 & 0.5 & 0.0 & 0.6 & 0.0 & 0.1 \\
\hline \multicolumn{10}{|l|}{ YT } \\
\hline & Larva and pupa & 0.0 & 0.0 & 0.0 & 0.0 & 0.0 & 0.0 & 0.0 & 0.0 \\
\hline & Adult & 0.0 & 0.0 & 0.0 & 0.0 & 0.0 & 0.0 & 0.0 & 0.0 \\
\hline
\end{tabular}

a) The stage of mango bud is shown in Fig. 1 .

Table 4. The number of $S$. dorsalis captured by Phito traps ${ }^{\text {a) }}$ in mango under plastic house

\begin{tabular}{lccccc}
\hline & & & \multicolumn{2}{c}{ No. of S. dorsalis } \\
\cline { 4 - 6 } Part of mango & No. & No. of trap & Larva & Pupa & Adult \\
\hline Soft wood & 5 & 55 & 0 & 0 & 0 \\
Trunk & 5 & 25 & 0 & 0 & 2 \\
Trunk collar & 5 & 50 & 0 & 0 & 0 \\
\hline
\end{tabular}

a) Phyto traps were put on 17 November 2014. The Number of S. dorsalis was countered on 9 January 2015. 


\section{引用 文 献}

鹿児島県病害虫防除所（2010）平成21年度病害虫発生 予察特殊報第 5 号.

高知県病害虫防除所（2008）平成20年度病害虫発生予 察特殊報第 1 号.

小池 朗・根本 久・天野 洋 (2000) カブリダニ捕 獲トラップ（Phyto trap）の開発抢よびその利用に よるナシ樹上のカブリダニ種構成と発生消長の調査. 応動昆 $44: 35-40$.

Masui, S (2007) Synchronism of immigration of adult yellow tea thrips, Scirtothrips dorsalis Hood (Thysanoptera: Thripidae) to citrus orchards with reference to their occurrence on surrounding host plants.Appl.Entomol.Zool. 42 : 517-523.

仲宗根福則・比嘉良次・長嶺将昭・金城美恵子（1996） 沖縄県で発生したマンゴーの害虫。 九病虫研会報 $42: 122-124$.

西野 操・小泊重洋（1988）チャノキイロアザミウマ. 農作物のアザミウマ.（梅谷献二・工藤 巌・宮崎 昌久編）。全国農村教育協会（東京）, pp. 442 .

農林水産省（2014）農林水産省統計データベース http://www.maff.go.jp/j/tokei/kouhyou/tokusan_ kazyu/（2017年 4 月24日アクセス確認）.

大林隆司（2003）マンゴー（アザミウマ類）.農業総覧 原色病害虫診断防除編 7 果樹 カキ・クリ・その 他追録第33号マンゴー害虫（農山漁村文化協会編）. 農山漁村文化協会 (東京), pp. 1-8.

岡田利承・工藤 嚴（1982）チャノキイロアザミウマ
の越冬場所と越冬態. 応動昆 $26: 177-182$.

Toda, S., T. Hirose, K. Kakiuchi, H. Kodama, K. Kijima, M. Mochizuki (2014) Occurrence of a novel strain of Scirtothrips dorsalis (Thysanoptera: Thripidae) in Japan and development of its molecular diagnostics. Appl. Entomol. Zool. 49 231-239.

土田 聡（2015）チャノキイロアザミウマC 系統の 特徴と遺伝子診断法. 植物防疫 $69: 28-32$.

柴尾 学・田中 寛（2003）ブドウにおけるチャノキ イロアザミウマの発育と生殖休眠に及ぼす日長の影

響. 応動昆中国支部会報 45:11-15.

柴尾 学・田中福三郎・佃 律子・藤崎憲治 (1991) ブドウ戒場に打けるチャノキイロアザミウマの越冬 場所と越冬態。応動昆 35（2）：161-163.

山口卓宏・岩元順二・後藤秀章・野島秀伸 $\cdot$ 尾松直 志・鳥越博明・安田耕司・瀬戸口脩・林川修二 （2006）奄美群島で発生が確認されたマンゴーの害 虫. 九病虫研会報 $52: 60-65$.

山口卓宏（2007）奄美大島のハウスマンゴーにおける チャノキイロアザミウマとアカオビアザミウマの花 芽，花房ならびに果実での発生推移。九病虫研究会 報 $53: 103-106$.

山中 聡（2009）スワルスキーカブリダニの特長と使 い方. 植物防疫 $63: 381-384$.

吉松孝宏・宮路克彦（2014）マンゴー戋場における チャノキイロアザミウマ2系統の発生消長. 九病虫 研会報 $60: 95$ (講要)。

(2017年4 月28日受領， 7 月28日受理) 